\title{
Chapter 6 \\ Cross-Border Forms of Animal Use by Indigenous Peoples
}

\author{
Stefan Kirchner
}

\begin{abstract}
The chapter discusses animal use by indigenous peoples that involve crossing state borders, using the example of reindeer herding by indigenous Sámi in Sweden, Norway, and Finland. Animals play important cultural, economic, and spiritual roles for indigenous communities. This particular form of interaction between humans and animals is, however, not sufficiently recognized by contemporary laws. The risk of overruling the interests of migratory animals, and of the pastoralist (semi-)nomadic human communities depending on them, is exacerbated when the herds cross boundaries.
\end{abstract}

\section{Introduction}

The aim of this essay is to show how international law relates to the interaction of indigenous peoples and animals across international borders. While colonial borders have affected the lives of herding communities in Africa and while there are crossborder indigenous activities in different parts of Latin America, the situation in Northern Europe is particularly noteworthy. This is because many kinds of cross-

\footnotetext{
Revised version of the original published article "Cross-Border Forms of Animal Use by Indigenous Peoples" by Stefan Kirchner, American Journal of International Law Unbound Volume 111, 2017, pp. 402-407. The original article was published as an Open Access article, distributed under the terms of the Creative Commons Attribution licence (http:// creativecommons.org/licenses/by/4.0/).
}

The author thanks Sámi friends and colleagues from Sweden, Norway and Finland for their insightful information about Sámi livelihoods. All opinions and errors contained in this text are only attributable to the author.

\footnotetext{
S. Kirchner $(\bowtie)$

University of Lapland, Arctic Center, Rovaniemi, Finland

e-mail: stefan.kirchner@ulapland.fi

(C) The Author(s) 2020

A. Peters (ed.), Studies in Global Animal Law, Beiträge zum ausländischen öffentlichen Recht und Völkerrecht 290, https://doi.org/10.1007/978-3-662-60756-5_6
} 
border activities are possible there, not simply because effective border controls are difficult to ensure in such remote areas, but mainly because several of the relevant states have the long-term political will to allow for cross-border activities. This freedom is not enjoyed by indigenous communities who have long called the area home. Particular attention will therefore be given to the situation of the indigenous Sámi people. Their homeland, Sápmi, is ruled by Norway, Sweden, Finland and Russia.

Home to the indigenous Sámi people for thousands of years, the region eventually saw the arrival of Germanic-speaking peoples from the south. ${ }^{1}$ For centuries, overwhelmingly large parts of Fennoscandia, with a few exceptions, were dominated by non-indigenous powers. The 1751 Peace Treaty of Strömstad created a border between Denmark (which at the time included Norway) and Sweden (which then also included Finland) included a supplement, the so called Lapp Codicil. This document guaranteed the continued practice of migratory ${ }^{2}$ Sámi reindeer herding in the region and therefore also across the newly created international border, ${ }^{3}$ as well as other traditional ways of livelihood, such as fishing. ${ }^{4}$ The practical reality in over the coming centuries, though, looked very different ${ }^{5}$ and the borders between Russia (which ruled Finland between 1809 and 1917) and Norway and Sweden were closed in 1852 and 1889 respectively. ${ }^{6}$ Russian rule over Finland also led to the effective end of representational rule, which also led to an end to the legal recognition of the Sámi community, the siida ${ }^{7}$ as a relevant political entity, even though it continued to remain relevant in the remote Northwestern part of Finland. ${ }^{8}$ The creation of national legislation on reindeer herding has moved the decision-making on reindeer herding ${ }^{9}$ from the traditional model of siida reindeer herding communities to the national administration and the reindeer herding associations. ${ }^{10}$ Also in the

\footnotetext{
${ }^{1}$ Broadbent, Lapps and Labyrinths 2010, ebook, position 4137. Note that, while still found in place names, the use of the term "Lapp" to refer to Sámi people is today considered offensive, Fuglerud, 'Positioned Creativity' 2016, 162. See also Brännlund/Axelsson, 'Reindeer management' 2011, 1097 et seq.

${ }^{2}$ The term 'migratory reindeer herding' refers to the practice to moving reindeer between summer and winter pastures (see Næss et al., 'Cooperative pastoral production' 2010, 249) which is still practiced in Sweden and Norway, but not in Finland.

${ }^{3}$ Heikkilä, Reindeer Talk 2006, 102.

${ }^{4}$ See Kent, Sámi Peoples 2014, 240.

${ }^{5}$ See Lantto, Borders, Citizenship and Change 2010.

${ }^{6}$ Heikkilä, Reindeer Talk 2006, 103. On the impact of borders on the Sámi people see also Seurujärvi-Kari/Carpelan, 'Regions and borders' 2005, 294-295 and Lehtola, Sámi People 2010, 78-79.

${ }^{7}$ See Kent, Sámi Peoples 2014, 228-229.

${ }^{8}$ Heikkilä, Reindeer Talk 2006, 113.

${ }^{9}$ For an overview over the situation in Norway and Finland see Heikkilä, Reindeer Talk 2006, 115-116.

${ }^{10}$ Heikkilä, Reindeer Talk 2006, 114. On the different levels of autonomy of reindeer herding communities in Norway, Sweden (in both countries only Sámi) and Finland (Sámi and non-Sámi) see Reinert, 'Economics of reindeer herding 2006, 537.
} 
other parts of Sápmi, the states play a dominant role in shaping and regulating reindeer herding and even in the areas which are recognized by the states as Sámi homelands, "reindeer herding has lost its primary land use status in favor of agriculture, forestry, mining industry, water power construction or tourism". ${ }^{11}$ This trend is only going to become more relevant as climate change is making large parts of the Arctic and Sub-Arctic more accessible to outside economic interests.

Today, cross-border reindeer herding in Sápmi is limited to the border between Norway and Sweden, while there is no cross-border reindeer herding involving Finland or Russia. European integration has not changed this situation: the borders between Norway, Sweden and Finland have been open since the Nordic Passport Union of 1952, significantly predating the Schengen Agreement of 1985, which allows for unhindered travel in large parts of Europe, including these countries. ${ }^{12}$ Finland and Sweden are members of the European Union, while Norway is part of the European Free Trade Area and of the Schengen Agreement, Russia imposes visa requirements on citizens of the three other states. With such limitations, the Russian part of Sápmi is effectively cut off from the Western parts. While the borders between Finland, Norway and Sweden have long been open for many purposes, this openness does not fully take into account the needs of the indigenous Sámi people, who consider themselves to be one people and consider the Sápmi homeland as a whole. ${ }^{13}$ This is reflected in ongoing disputes concerning the legal basis for cross-border reindeer herding between Norway and Sweden. Today, only part of their ancestral homeland is recognized as Sámi home areas in the legal sense of the term and the Sámi are a minority in their own regions virtually throughout Sápmi. ${ }^{14}$

\footnotetext{
${ }^{11}$ Heikkilä, Reindeer Talk 2006, 115.

${ }^{12}$ The Schengen acquis as referred to in Article 1(2) of Council Decision 1999/435/EC of 20 May 1999, Agreement between the Governments of the States of the Benelux Economic Union, the Federal Republic of Germany and the French Republic on the gradual abolition of checks at their common borders, Official Journal 2000 L 239, available at http://eur-lex.europa.eu/legal-content/ EN/TXT/PDF/?uri=OJ:JOL_2000_239_R_0001_01\&from=EN, 22 September 2000, pp. 13-18, for the implementation of the Schengen agreement see the Convention implementing the Schengen Agreement of 14 June 1985 between the Governments of the States of the Benelux Economic Union, the Federal Republic of Germany and the French Republic on the gradual abolition of checks at their common borders, ibid., pp. 19-26; for the accession to the latter by Finland and Sweden see ibid., pp. 106-114 and pp. 115-123, respectively.

${ }^{13} \mathrm{Cf}$. United Nations Regional Information Centre for Western Europe, The Sami of Northern Europe - one people, four countries, available at http://www.unric.org/en/indigenous-people/ 27307-the-sami-of-northern-europe\%2D\%2Done-people-four-countries.

${ }^{14}$ Also the part of Finland in which reindeer herding is conducted is significantly larger than the Sámi home area. For a map of the former see Åsbakk/Kumpula/Oksanen/Laaksonen, 'Infestation' 2014, 173, for a definition for the latter see Section 4 of the Finnish Act on the Sámi Parliament, 974/1995, as amended, unofficial translation by the Ministry of Justice, Finland, available at https:// www.finlex.fi/en/laki/kaannokset/1995/en19950974.pdf.
} 


\section{Traditional Livelihoods of a Transnational Indigenous People}

Reindeer herding is an important source of income for many indigenous communities in the Arctic and Sub-Arctic, ${ }^{15}$ especially in the Nordic countries and Russia. Reindeer are owned but for almost all practical purposes are free to roam large, but delimited, areas. In Norway and Sweden the human-reindeer interaction involves seasonal migration between summer pastures at higher altitudes and winter pastures closer to the sea.

In Norway and Sweden only indigenous persons have the right to herd reindeer, whereas every EU citizen, enjoying the freedom to work across borders, is free to own and herd reindeer in Finland. In Sweden, the right to herd reindeer is held by the local sameby, the Sámi Village. While serving as a reminder of the traditional Sámi unit of organization, the siida, these entities, despite their name, have been created by the state for the purpose of managing the right to herd reindeer. Each sameby holds the right to herd reindeer in a long thin strip of land, generally ranging from the mountains in the West to the sea in the East. While there are still many parallels to traditional Sámi forms of organizing and managing reindeer herding, the framework for reindeer herding is controlled by the state rather than by indigenous communities. Today, reindeer herding is a business like many others and the state's view on reindeer herding can be summarized to the effect that "reindeer herding is about managing privately owned capital (the reindeer) on a common resource base (the pasture)". ${ }^{16}$ Land use conflicts between reindeer herding and other land uses, such as forestry, ${ }^{17}$ and the decreasing availability of land suitable for reindeer herding put significant economic stresses on Sámi reindeer herders, which come on top of decades long declines in the incomes of Sámi reindeer herders. ${ }^{18}$

In Finland, indigenous reindeer herding families are even more constrained by the legal framework created by the state: reindeer herding is organized through reindeer herding associations (paliskunnat). ${ }^{19}$ Within a paliskunta, decisions are made by the majority, but because non-indigenous persons may herd reindeer, too, it is possible for Sámi reindeer herders to be in the minority. As a result, the traditional ways of herding reindeer have been abandoned in many paliskunnat. In one paliskunta, the non-indigenous majority sets the numbers of reindeer to be slaughtered, which effectively forced indigenous reindeer herding families in one part of the paliskunta to slaughter all of their reindeer. ${ }^{20}$

As a result of the national regulation of reindeer herding, today there is no longer any transboundary reindeer herding in Sápmi: while the free movement of persons is

\footnotetext{
${ }^{15}$ Stoyanova. 'Saami facing the impacts' 2013, 291.

${ }^{16}$ Heikkilä, Reindeer Talk 2006, 133 et seq., italics omitted.

${ }^{17}$ Cf. Roturier/Roué, 'Of Forest, Snow and Lichen' 2009, 1960.

${ }^{18} \mathrm{Cf}$. Reinert, 'Economics of Reindeer Herding' 2006, 523.

${ }^{19}$ See in detail Mustonen/Jones, Reindeer Herding in Finland 2015, 4 et seq.

${ }^{20}$ Human Rights Committee, Kalevi Paadar et al. v. Finland, Communication No. 2102/2011 of 10 April 2014, U.N. Doc. CCPR/C/110/D/2102/2011 (2014).
} 
permitted under the Schengen Agreement and many people in the region cross borders on a regular basis, reindeer herding is regulated on the national levels. This has long been a problem for Sámi reindeer herders. ${ }^{21}$

This indicates a stronger role for the nation state in a region which has long been defined by shared cultures rather than borders. Centuries ago, the Sámi were taxed by different sovereigns. Today, although their way of life has not been entirely robbed of its transnational dimension, their best-known traditional livelihood has been restricted by borders that were created without the doing of the indigenous communities affected. Despite the fact that most Sámi depend primarily on other sources of income, reindeer herding remains an important part of Sámi culture.

\section{Involving Indigenous Peoples in Decision-Making Processes and Protecting Their Rights in International Agreements}

One important problem of indigenous rights in the Arctic is the involvement of indigenous communities in decision-making processes. Today, national Sámi Parliaments in Norway, Sweden and Finland play important roles in giving the Sámi people a voice on the national level, for example, in the context of mining permits. However, the rights of indigenous peoples are at risk of being ignored by national governments engaging in international relations.

For example, the lack of Sámi participation was criticized recently in the context of the Deatnu River Agreement between Finland and Norway. The Deatnu River (Finnish: Tenojoki, Norwegian: Tanaelva) forms part of the border between Finland and Norway in the homeland of the Sámi people. Next to reindeer herding, fishing is a key traditional livelihood of the Sámi people. The Deatnu River is one of the best salmon rivers worldwide and attracts tourists from around the world due to its remarkable water quality and the size of the salmon caught there. This sets the stage for a usage conflict between indigenous and non-indigenous actors. The agreement between Finland and Norway restricts traditional indigenous fishing rights in the Sámi heartland, which de facto allows for the development of fishingbased tourism in the region. While fishing and tourism are important sources of income for this region of Europe, fishing is a crucial element of Sámi culture as well. This is particularly so not only along the coasts but especially in the North-Eastern part of Finland and in Norway.

By agreeing on the distribution of the right to fish in the border river without taking sufficient account of the local indigenous communities, ${ }^{22}$ Finland and

\footnotetext{
${ }^{21}$ See already Elbo, 'Norwegian-Finnish reindeer fence' 1954, 73-74.

${ }^{22}$ For an overview over the fishing regulations under the agreement between Finland and Norway see Ministry of Agriculture and Forestry Centre for Economic Development, Transport and the Environment/Fisheries Division LUKE/Natural Resources institute Finland/ River Tenojoki
} 
Norway risk violating the rights of the indigenous Sámi to be heard, their right to be consulted (under ILO Convention No. 169 for Norway and, arguably more far-reaching, under customary international law for Finland, which has not yet ratified the Convention), and their right to engage in sustainable livelihoods. ${ }^{23}$

One notable exception to the lack of Sámi participation is the Sámi Parliaments' role in drafting the proposed 'Nordic Saami Convention' ('Saami' is an alternative spelling for 'Sámi'). The need for a regional treaty arose due to the limited of protection of indigenous rights under existing norms, as the next paragraphs will explain.

The transnational reality of Sámi identity is not recognized in international law, a problem this group shares with many other transnational indigenous peoples. In general, unlike in the Inter-American human rights system, indigenous rights have hardly played a role at the European Court of Human Rights. ${ }^{24}$ The European Convention on Human Rights (ECHR), which has been ratified by the four states in question, only protects indigenous livelihoods in the context of the right to private life (Article 8 of the ECHR). ${ }^{25}$

Some Sámi litigants have sought protection of their rights under Article 27 of the International Covenant on Civil and Political Rights (ICCPR), also ratified by the four states, and some work has been undertaken in Europe on national minorities. Article 27 of the ICCPR remains a norm of central importance in the context of indigenous rights, especially as ILO Convention No. 169 has not been ratified by key states in the region, including Sweden, Finland and Russia, and the 2007 UN Declaration on the Rights of Indigenous Peoples (which in large parts reflects the existing customary international law) is non-binding as it was adopted by the UN General Assembly. The importance of Article 27 of the ICCPR is reflected in the range of cases in which it has been invoked, many of which originated from Sápmi. According to Article 27, minorities, including indigenous communities, have the right to enjoy their culture. This has long been understood to include cultural activities which have the purpose of making a living, including reindeer herding for profit. The wording of Article 27 of the ICCPR, which dates back to the 1960s, however, shows that existing international human rights norms are still too dependent on the current state-centered system of international law in order to fully take into account the needs of transnational indigenous peoples: the rights under Article 27 of the ICCPR only apply "[i]n those States, in which ethnic, religious or linguistic minorities exist". ${ }^{26}$ There is no transnational element in Article 27 of the ICCPR which would allow for cross-border reindeer herding.

Fisheries Research, Information about Teno for Fishing Enthusiasts (2017), available at https:// www.ely-keskus.fi/documents/10191/23117928/Teno+info+English.pdf/1a185302-fa5d-4ba6bd90-17183fefdf 21 .

${ }^{23}$ On the negative consequences of outside stressors under traditional and modern reindeer herding models see Burkhard/Müller, 'Case study northern Fenno-Scandinavian reindeer herding' 2008, 829 et seq.

${ }^{24}$ But see e.g. Koivurova, 'Jurisprudence' 2011.

${ }^{25}$ See European Commission of Human Rights, G. and E. v. Norway, Applications Nos 9278/81 and 9415/81, Decision of 3 October 1983.

${ }^{26}$ Art. 27 ICCPR. 
The United Nations Declaration on the Rights of Indigenous Peoples (UNDRIP) could have been an important step towards closing this gap-and the development of customary international law in the years since then is not to be underestimated-but the UNDRIP was adopted 'only' by the General Assembly of the United Nations. It therefore is not a binding document per se. While UNDRIP is contributing to the development of customary international law, codifications, especially 'user-friendly' codifications, are a hallmark of the legal systems of the Nordic states. It is therefore hardly surprising that there has long been a desire to clarify in a written instrument the legal situation of the Sámi people across borders.

Today, even the definition of who is actually Sámi varies between the states because the states have set different criteria for the eligibility to participate in the elections to the respective national Sámi Parliaments. In recent years, negotiations have been underway between Norway, Finland and Sweden to establish an international treaty, the Nordic Saami Convention, to unify the legal position of the Sámi people at least in three of the four countries in question. The national Sámi Parliaments played an important role in the drafting process, thereby expanding the realm of consultation of indigenous communities from the national to the transnational-in accordance with the cultural reality of the Sami people, who consider themselves to be one people, regardless of languages and passports.

The attempt at involving indigenous representatives in the making of a new international treaty is a laudable development, but due to the long passage of time during which reindeer herding has already been regulated on the national level and within national borders, this move might come too late for Sámi reindeer herders. At this time, a revival of old — sustainable_-patterns of reindeer herding, regardless of national borders, appears if not impossible then at least highly unlikely. The revival of some Sámi languages in recent years has been an important cultural development, but the recognition of traditional ways of reindeer herding appears to face too many obstacles, not least in the form of competing land use claims, to be a realistic option in the foreseeable future.

In the case of the fishing rights in the Deatnu river it would have been much easier for the two nations, which have long enjoyed excellent relations, to come to a solution which would have allowed the realization of transnational animal use rights by the Sámi people living on both sides of the river. This opportunity was not only missed when the economic interests of the nation states areas were given precedence over indigenous needs and traditions, but also when both states failed to let the affected Sámi people weigh in sufficiently.

\section{Animals, Welfare, Animal Welfare and Indigenous Culture}

The failure of states to adequately involve transnational indigenous communities in decision-making processes can also have an impact on the welfare of the animals in question. This is particularly the case when the state imposes ways of handling 
animals which are at odds with methods that have long been known to be sustainable and holistic, in the sense that they might be beneficial for the overall herd and the community. This, however, does not mean that indigenous approaches are always best from the perspective of the welfare of the individual animal. The approach taken by indigenous communities that depend on animals for their survival is usually dominated by pragmatism rather than contemporary animal welfare discussions. Reindeer herding remains an important element of Sámi culture even though today many indigenous persons have other sources of income. Not only is reindeer meat a regionally important source of food, many traditional products are made from reindeer parts—-such as antlers or hide.

That said, often the way that Sámi communities treat animals is significantly closer to the needs of animals than factory-based meat production would allow. For example, unlike caribou in North America, ${ }^{27}$ reindeer in Sápmi are no longer hunted ${ }^{28}$ but herded. ${ }^{29}$ The animals are owned by the herders but not fully domesticated in the same way as farm animals are. Far from it, they roam large areas fairly freely and are only collected in autumn ${ }^{30}$ or, in Sweden and Norway, during the seasonal migrations between summer and winter pastures. ${ }^{31}$ For Sámi reindeer herders, the wellbeing of the animals is essential for their own wellbeing. Indeed, meat production is only one purpose of reindeer herding; other parts of the animals are used for the production of culturally relevant products. The cultural, not merely practical, importance of caring for reindeer differentiates this form of animal use from other animal-related livelihoods, including ranching, hunting or fishing. Indeed, economic profit was never a main goal of reindeer herding. In addition to providing food security, the cultural dimension of hunting, herding and fishing is not to be underestimated. Often key animals take on a highly symbolic value for indigenous cultures. Especially for (semi-)nomadic indigenous communities, as commonly found in the Arctic and Sub-Arctic, gatherings are associated with traditional forms of animal-related livelihoods. For transboundary (semi-)nomadic indigenous peoples like the Sámi, such gatherings are also important cultural events. By reorganizing the traditional cultural activity of reindeer herding within different national legal frameworks, not only the traditional way of life but also the culture of the indigenous Sámi people has been affected.

\footnotetext{
${ }^{27}$ See Alaska Department of Fish and Game, Caribou Hunting in Alaska, available at: http://www. adfg.alaska.gov/index.cfm? adfg = caribouhunting. main.

${ }^{28}$ On historic Sámi reindeer hunting see Snatic, Hunting and Gathering, available at: https://www. laits.utexas.edu/sami/diehtu/siida/hunting/jonsa.htm. Elsewhere, hunting and poaching remain a serious threat to the survival of reindeer, for example on Russia's Taymyr peninsula, see (no author names), 'How poaching is "killing off" the world's largest reindeer herd on Taimyr Peninsula', in: Siberian Times, 7 February 2017, available at: http://siberiantimes.com/ecology/casestudy/features/ f0285-how-poaching-is-killing-off-the-worlds-largest-reindeer-herd-on-taimyr-peninsula/.

${ }^{29} \mathrm{Cf}$. Riseth/Tømmervik/Bjerke, ‘175 years of adaptation’ 2016.

${ }^{30}$ Mustonen/Jones, Reindeer Herding 2015, 3.

${ }^{31} \mathrm{~A}$, somewhat, similiar approach to herding is also found among some shepherding communities in Britain's Lake District, see Rebanks, Shepherd's Life 2016, 9 et seq.
} 
The situation in Sweden illustrates rather dramatically the need for national law-makers to respect traditional cultures as all indigenous land rights are dependent on reindeer herding, Swedish law not recognizing other forms of indigenous land rights, e.g. for fishing.

All over the European Arctic, reindeer herding cannot be understood completely without looking at the problems and challenges surrounding indigenous land rights, ${ }^{32}$ be it full ownership or usage rights. ${ }^{33}$ Usage rights are particularly relevant in areas where the state claims ownership of large areas of land, like in Norway and Finland. ${ }^{34}$ Ancient indigenous ways of life, which are based on many generations of land use, often conflict with modern, state-centered, approaches to land use and land use conflicts. ${ }^{35}$ Often it will be difficult, if not impossible, for Sámi reindeer herders to provide evidence which holds up in today's courts to show this long history of land use of non-owned lands for herding purposes. ${ }^{36}$

In Finland, the right to herd reindeer is not even restricted to indigenous persons or groups but in theory every EU citizen can join a reindeer herding association. The traditional Sámi methods of reindeer herding are being replaced by methods favored by the Association of Reindeer Herding Districts and the Ministry of Agriculture, ${ }^{37}$ both of which are dominated by non-indigenous actors. This difference in approaches to reindeer herding has consequences for animals, humans and the wider environment. While the modern, non-indigenous, approach places emphasis on food production, ${ }^{38}$ "Sámi reindeer herders [...] see reindeer herding usually in a more holistic sense, as a way of life in which the economic, ecological, social, and cultural aspects are closely intertwined. Reindeer herding is seen as an inseparable part of life" 39 and Sámi culture.

Other concerns are even more pressing from the perspective of indigenous reindeer herders: while climate change is a long-term problem, which already has direct effects on reindeer herding ${ }^{40}$ and which devalues traditional indigenous knowledge $^{41}$ the more immediate threat to both animals and indigenous reindeer herders stems from increased land use conflicts. Mining, forestry and the construction of infrastructure not only take away the possibility for reindeer to roam freely, they also endanger the natural environment and reduce food security for the animals and therefore also for the Sámi reindeer herders. Animal welfare is scarcely taken

\footnotetext{
${ }^{32}$ Heikkilä, Reindeer Talk 2006, 96.

${ }^{33}$ Cf. Heikkilä, Reindeer Talk 2006, 97.

${ }^{34}$ Ibid., 97.

${ }^{35}$ Ibid., 98 et seq.

${ }^{36}$ See for example European Court of Human Rights, Handölsdalen Sami Village and others v. Sweden, Application No. 39014/04, Judgment of 30 March 2010.

${ }^{37}$ Heikkilä, Reindeer Talk 2006, 59.

${ }^{38}$ Ibid., 90.

${ }^{39}$ Ibid., 93.

${ }^{40}$ See Tyler et al., 'Saami reindeer pastoralism 2007, 194 et seq.

${ }^{41}$ Ford/Smit/Wandel, 'Vulnerability' 2006, 150.
} 
into account, which might also be due to a lack of information among decisionmakers in Stockholm, Oslo and Helsinki despite the wealth of already existing scientific research on reindeer. This situation reflects the relative economic importance of reindeer herding: from a national perspective, reindeer herding is a "marginal industry"42 and indeed in Finland (as opposed to Norway ${ }^{43}$ ) it is not recognized as a "formal" 44 form of income but "it appears to be mostly a curiosity". ${ }^{45}$ On the local level, however, in particular in the border region between Finland and Norway, reindeer herding remains an important source of income and field of employment. ${ }^{46}$ The consideration given by the authorities to reindeer herders, especially in Norway, where only Sámi herd reindeer, has had the detrimental side effect that interventionism has made reindeer herding less sustainable than it could be: "The Norwegian political system has generally failed to consider reindeer herding as a business. Rather the preferred solution of successive governments of all political colours to the problems facing the herding industry has been to increase the level of economic support to the Saami herders, in effect putting them on the dole." ${ }^{47}$ The loss of accessible land cannot be compensated easily and so far measures taken by states have not had the effect of (re-)creating an environment in which sustainable reindeer herding is possible.

\section{Concluding Remarks}

Animals play important cultural, economic and spiritual roles for indigenous communities. However, contemporary law does go far enough in recognizing this particular form of interaction between humans and animals. Treating indigenous livelihoods like farming or ranching like non-indigenous counterparts means that significant cultural aspects are overlooked and that indigenous knowledge regarding the wellbeing of animals is often disregarded by political decision-makers. Climate change and increased land uses already threaten traditional ways of life in the North. The situation is worsened by the continued separation of the Sámi people by state borders. Today, there is no single form of Sámi reindeer herding but instead there are stark differences between the four states. The same applies to a great extent to fishing. The borders between the countries ruling Sámi (with the exception of Russia) were opened in the twentieth century. Yet, similar to the situation in North America despite the 1794 Jay Treaty, the borders are still very real for indigenous peoples. The way of life of many indigenous communities is dependent on the

\footnotetext{
${ }^{42}$ Heikkilä, Reindeer Talk 2006, 90.

${ }^{43}$ Ibid., 90.

${ }^{44}$ Ibid., 90.

${ }^{45}$ Ibid., 90 .

${ }^{46}$ Ibid., 91.

${ }^{47}$ Reinert, The Economics 2006, 537.
} 
behavior of animals. Migratory animals are not constrained by international borders. In many places around the world, pastoralist (semi-)nomadic herding has conflicted with sedentary agriculture for many centuries. Today, conflicts between settlers and indigenous communities are usually understood from the perspective of the dominant part of society, that is, the settler community (many members of which are unaware of the historical background and the land rights of indigenous peoples). In many cases, such conflicts turn on the needs of different animals, for example freeranging reindeer as opposed to grazing cattle or other animals usually associated with farming. Through the dominance of the settler society, the needs of farmingand ranching-related animals, as well as other interests such as the construction of infrastructure and other economic activities that require land, are given precedence over the interests of wild or semi-domesticated animals on which the livelihoods of indigenous people depend. Often specific indigenous needs are seen as conflicting with the interest of the state, which means that politically, indigenous interests can be framed as conflicting with what is perceived as the 'common' good.

This risk is particularly acute in the Nordic countries due to a political and legal emphasis on equality, which leads to widespread political opposition to what is perceived as additional rights for special interest groups. While this is changing, the move towards better protection of indigenous rights is not a straightforward process. Discrimination against Sámi persons is still widespread, despite the general commitment to human rights in Norway, Finland and Sweden. A limited recognition of indigenous rights also has direct effects on the well-being of animals associated with indigenous communities.

\section{References}

Åsbakk, K., Kumpula, J., Oksanen, A., \& Laaksonen, S. (2014). Infestation by Hypoderma tarandi in reindeer calves from northern Finland - Prevalence and risk factors. Veterinary Parasitology, 200, 172-178.

Brännlund, I., \& Axelsson, P. (2011). Reindeer management during the colonization of Sami lands: A long-term perspective of vulnerability and adaptation strategies. Global Environmental Change, 21, 1095-1105.

Broadbent, N. D. (2010). Lapps and Labyrinths: Saami prehistory, colonization and cultural resistance. Washington, DC: Smithsonian Institution Scholarly Press, ebook, position 4137.

Burkhard, B., \& Müller, F. (2008). Indicating human-environmental system properties: Case study northern Fenno-Scandinavian reindeer herding. Ecological Indicators, 8, 828-840.

Elbo, J. G. (1954). The Norwegian-Finnish reindeer fence. Polar Record, 7, 73-74. Available at: https://doi.org/10.1017/S0032247400043138.

Ford, J. D., Smit, B., \& Wandel, J. (2006). Vulnerability to climate change in the Arctic: A case study from Arctic Bay, Canada. Global Environmental Change, 16, 145-160.

Fuglerud, Ø. (2016). Positioned creativity: Museums, politics and indigenous art in British Columbia and Norway. In M. Svašek \& B. Meyer (Eds.), Creativity in transition - Politics and aesthetics of cultural production across the globe (pp. 158-184). New York: Berghahn.

Heikkilä, L. (2006). Reindeer talk: Sámi reindeer herding and nature management. Rovaniemi: Lapland University Press. 
Kent, N. (2014). The Sámi peoples of the North: A social and cultural history. London: Hurst \& Company.

Koivurova, T. (2011). Jurisprudence of the European Court of Human Rights regarding Indigenous peoples: Retrospects and prospects. International Journal of Minority and Group Rights, 18, $1-37$.

Lantto, P. (2010). Borders, citizenship and change: The case of the Sami people, 1751-2008. Citizenship Studies, 5, 543-556.

Lehtola, V.-P. (2010). The Sámi People: Traditions in transition. Aanar/Inari: Kustannus-Puntsi.

Mustonen, T., \& Jones, G. (2015). Reindeer Herding in Finland. Lampeter: European Forum on Nature Conservation and Pastoralism. Available at: http://www.snowchange.org/pages/wp-con tent/uploads/2015/06/Reindeer-herding-in-Finland.pdf

Rebanks, J. (2016). The Shepherd's Life - A tale of the Lake District. London: Penguins Books.

Reinert, E. S. (2006). The economics of reindeer herding - Saami entrepreneurship between cyclical sustainability and the powers of state and oligopolies. British Food Journal, 108, 522-540.

Riseth, J. Å., Tømmervik, H., \& Bjerke, J. W. (2016). 175 years of adaptation: North Scandinavian Sámi reindeer herding between government policies and winter climate variability (1835-2010). Journal of Forest Economics, 24, 186-204.

Roturier, S., \& Roué, M. (2009). Of Forest, Snow and Lichen: Sámi Reindeer Herders’ Knowledge of Winter Pastures in Northern Sweden. Forest Ecology and Management, 158, 1960-1967.

Seurujärvi-Kari, I., \& Carpelan, C. (2005). Regions and borders. In U.-M. Kulonen, I. SeurujärviKari, \& R. Pulkkinen (Eds.), The Saami: A Cultural Encyclopedia (pp. 294-295). Helsinki: Suomalaisen Kirjallisuuden Seura.

Snatic, J. Hunting and Gathering by the Sami. Available at: https://www.laits.utexas.edu/sami/ diehtu/siida/hunting/jonsa.htm.

Stoyanova, I. L. (2013). The Saami facing the impacts of global climate change. In R. S. Abate (Ed.), Climate change and Indigenous Peoples: The search for local remedies (pp. 287-312). Cheltenham/Northampton: Edward Elgar.

Tyler, N. J. C., et al. (2007). Saami reindeer pastoralism under climate change: Applying a generalized framework for vulnerability studies to a sub-arctic social-ecological system. Global Environmental Change, 17, 191-206.

Warg Næss, M., Bårdsen, B.-J., Fauchald, P., \& Tveraa, T. (2010). Cooperative pastoral production - the importance of kinship. Evolution and Human Behavior, 31, 246-258, 249.

Stefan Kirchner is Associate Professor of Arctic Law at the Arctic Centre of the University of Lapland in Rovaniemi, Finland, a visiting senior researcher at the Faculty of Law of Vytautas Magnus University in Kaunas, Lithuania, and invited professor (Jean Monnet Module) at V. N. Karazin University in Kharkiv, Ukraine. He has been visiting professor for Transitional Justice at the Faculty of Law of the University of Torino, Italy. Formerly a practicing lawyer in Germany, his current research interests include the governance of marine spaces in the Arctic and areas beyond national jurisdiction, in particular space law. 
Open Access This chapter is licensed under the terms of the Creative Commons Attribution 4.0 International License (http://creativecommons.org/licenses/by/4.0/), which permits use, sharing, adaptation, distribution and reproduction in any medium or format, as long as you give appropriate credit to the original author(s) and the source, provide a link to the Creative Commons licence and indicate if changes were made.

The images or other third party material in this chapter are included in the chapter's Creative Commons licence, unless indicated otherwise in a credit line to the material. If material is not included in the chapter's Creative Commons licence and your intended use is not permitted by statutory regulation or exceeds the permitted use, you will need to obtain permission directly from the copyright holder. 